\title{
EDITORIAL
}

\section{International Criminal Law: Over-studied and Underachieving?}

\author{
ELIES VAN SLIEDREGT*
}

\section{INTRODUCTION}

In his recent review of Neil Boister's book, An Introduction to Transnational Criminal Law, ${ }^{\mathrm{I}}$ Robert Currie praises the author for shedding light on a field of law that has suffered from inattention. ${ }^{2}$ Transnational criminal law (TCL), the 'other' branch of what was traditionally called international criminal law, has been overshadowed by international criminal law 'proper' (ICL). The establishment of international criminal tribunals after the end of the Cold War, culminating in the establishment of the 'flagship' court, the International Criminal Court (ICC), ${ }^{3}$ came with a spectacular rise of ICL as a separate legal discipline. As a result, ICL stole the limelight at the expense of TCL. Currie deplores this since TCL presents features and issues that are worthy and in pressing need of in-depth study. ${ }^{4}$ Also, in his view the attention to ICL is unjustified: ICL 'as an academic and legal inquiry or study has become distended by over-study'. ${ }^{5}$ While he supports the mission of international criminal justice in general, Currie points out that ICL as an academic discipline is saturated; each article, paragraph and subparagraph of the ICC Statute has been pulled apart and dissected. ${ }^{6}$ He submits:

Eager graduate students the world over continue to pen papers and theses that put forward theories of criminal responsibility or consider the fortunes of a crimes against humanity convention, the stars in their eyes made brighter by the popularity, excitement and academic sexiness of the field. ${ }^{7}$

Editorial board, Professor of Criminal Law, Director Center for International Criminal Justice (www.cicj.org), Vrije Universiteit Amsterdam. Chair of comparative and international criminal law, School of Law, University of Leeds [e.van.sliedregt@vu.nl].

I N. Boister, An Introduction to Transnational Criminal Law (2OI2).

2 R.J. Currie, 'Neil Boister. An Introduction to Transnational Criminal Law (Oxford University Press 20I2)', (20I5) I3 JICJ (via advance access): jicj.oxfordjournals.org/content/early/recent.

3 K. Anderson, 'The Rise of International Criminal Law: Intended and Unintended Consequences', (2009) 20 EJIL 33I.

4 Currie mentions the fact that TCL is premised on a crime control model, which brings with it the danger of over-criminalization. Currie, supra note 2, at 4 .

Currie, supra note 2, at I.

Ibid.

Ibid. 
Currie's description of ICL as an en vogue discipline that unjustifiably overshadows TCL resonates with me. It is true that TCL has been overlooked. If only for its practical value, in terms of 'usefulness' in practice, TCL deserves much more attention than ICL. Those who work as criminal law practitioners and policy makers will agree that TCL is much more part of the day-to-day work than ICL is.

Currie's words are an invitation to reflect on ICL scholarship and its future, especially bearing in mind the modest achievements in legal practice. Indeed, there is no positive correlation between the performance of the ICC and the scholarly interest in ICL. By its $4^{\text {th }}$ year of existence, the ICC only carried through from indictment to judgment, three trials: the Lubanga, Ngudjolo and Katanga cases. Lubanga and Ngudjolo are the only cases that have been decided on appeal. Despite this slow pace, ICL scholarship does not show signs of recession.

In this editorial I wish to follow up on the editorials written by Sergey Vasiliev and Dov Jacobs in two previous issues of the Leiden Journal of International Law (LJIL), pondering on the future of ICL scholarship. I realize I risk being criticized for giving ICL more attention than it deserves in a journal on international law. Truth is, ICL is still the subject of the majority of submissions to the Journal. Aside from that, most of the issues I touch upon concern legal scholarship more generally.

\section{ICL'S ATTRACTION}

So what explains the attraction of ICL? I can think of a number of reasons. First of all, the gloss of novelty. The establishment of the ad hoc tribunals for the former Yugoslavia and Rwanda in the early nineties marked the beginning of ICL as a fullblown legal discipline. The excitement of being part of a new project, of building a new justice system, has attracted many to specialize and work in ICL. Even now, while the gloss of novelty may have faded, ICL retains its appeal. Unlike national criminal law, which has developed over centuries and is firmly grounded in the institutionalized set-up of states, ICL is a young discipline. Also, its object of study, the international criminal justice system, is far from finished. To the contrary, it is incoherent, pluralist, and as a result prone to sudden transformations. ${ }^{8}$ When the ICTY Appeals Chamber acquitted general Perišić because there was no evidence that his assistance was 'specifically directed' at the commission of crimes, debates exploded on social media, in law journals, blogs and undoubtedly in many a research paper and master thesis. With the Perišić Appeals Chamber judgment, ${ }^{9}$ a long line of precedent aiding and abetting-liability had been set aside without convincing reasoning. ${ }^{\text {IO }}$ The fact that the Appeals Chamber, I I months later in Sainovic, ${ }^{I I}$ in a different composition, turned back the clock to the pre-Perišićsituation and rejected

8 J.V.H. Holtermann and M. Rask Madsen, 'European New Legal Realism and International Law: How to Make International Law Intelligible', (20I5) 28 LJIL 22 I, at 224.

9 Prosecutor v. Perišić, Judgement, Case No. IT-04-8I-A, A. Ch., 28 February 2013.

Io A. Coco and T. Gal, 'Losing Direction. The ICTY Appeals Chamber's Controversial Approach to Aiding and Abetting in Perišić', (20I4) I 2 JICJ 345; L.N. Sadat, 'Can the ICTY Šainović and Perišić Cases Be Reconciled?', (20I4) I08 AJIL 475.

I I Prosecutor v. Sainović et al., Judgement, Case No. IT-05-87-A, A. Ch., 23 January 2014. 
the 'specific direction' criterion as if nothing had happened, shows how unstable the international criminal justice system is. Without going into the details and intricacies of these cases, it is not hard to imagine that ICL as a legal system leaves much room for commentary, debate, critique and even speculation (were there political motives behind this change in law?).

A second explanation or reason for ICL's attraction, closely related to the first, is what can be called norm entrepreneurialism. It is no secret that certain states are keen to export the moral impulses that underpin their domestic criminal laws into the international realm. One of the clearest examples is probably France's efforts to install a pre-trial phase into ICC proceedings and to provide for victim representation at the ICC. There is the strong - and not unjustified-assumption that ICL can benefit from domestic criminal law practice and theories. The concerted effort of German scholars to import German theories on crime-attribution into ICL is prompted by the conviction that it will improve the law on criminal responsibility at the ICC. Norm entrepreneurialism explains why ICL appeals to comparative criminal law scholarship. Also for me, ICL's main attraction lies in its comparative law side; not so much because of the possibility to export domestic norms but mainly for studying the amalgamation of legal cultures and traditions. When it comes to legal pluralism and harmonization of norms, ICL has much to offer.

A short note of caution is appropriate here: While norm entrepreneurialism and the practice of transplanting and borrowing legal concepts from foreign jurisdictions, is an established practice in a globalized world, there is something problematic about it when it concerns ICL. First of all, because it is not self-evident that domestic criminal law concepts and practices are appropriate and 'fitting' for the type of criminality and trials that international courts deal with. Secondly, because there is no coherent and uniform legal community at the international level, norm entrepreneurialism ends up creating a hodge-podge of law, which will increase misunderstandings and division amongst legal practitioners who come from different legal traditions and backgrounds. ${ }^{\mathrm{I} 2}$

A third reason for ICL's popularity is the 'story' of ICL: International crimes are the most serious violations of international law. The increasingly popular label 'mass atrocity crimes' signals the abhorrent and systemic nature of international crimes, with genocide, regarded as the 'crime of crimes', at the apex of international criminality. The grave nature and scale of international crimes, and the fact that they impact upon international peace and security, magnifies many of the issues at stake. International trials are framed as historical moments and the trials themselves are regarded as contributing to a historical narrative. ${ }^{\text {I3 }}$ It is no surprise that ICL captures the imagination. The story is simple and has classic ingredients: evil, justice and a

I2 See for instance, the debates on the (perceived) difference between co-perpetration and joint criminal enterprise: E. van Sliedregt, 'Joint Criminal Enterprise as a Pathway to Convicting Individuals for Genocide', (2007) 5 JICJ I 84.

I 3 S. Stolk, "The Record on Which History Will Judge Us Tomorrow”: Auto-History in the Opening Statements of International Criminal Trials', (2015) 28 LJIL 993. 
hero. ${ }^{14}$ This is not just how 'outsiders' perceive ICL. Sofia Stolk, in her work on opening statements in international trials, shows how international prosecutors, in an attempt to construe the legitimacy of a trial, use grand words and magnify their role in fighting impunity and securing justice for victims. ${ }^{15}$ We see this reflected in Hollywood-style documentaries like The Prosecutor and The Reckoning where prosecutors are heroes who single-handedly fight evil. The story of ICL has attracted an eclectic group of supporters, human rights activists and scholars, all united in the quest for justice. Noteworthy is the relationship between civil society and ICL. The ICC has its 'own' group of NGOs that supports and monitors its functioning. Under the banner of the Coalition of the ICC (CICC), NGOs engage with the Court. Civil society was instrumental in setting up the ICC in Rome and, that way, earned itself a permanent seat at the negotiating table.

This brings me to the fourth reason for ICL's popularity: ICL as a foreign policy tool. Setting up an international justice system is less controversial than humanitarian intervention and any other measure that would violate state sovereignty. According to Kenneth Anderson, '[i]nternational criminal law emerged partly because great powers saw it as an alternative to more forceful action in situations of massive human rights violations - but in which they could not see their individual interests in intervening directly'. ${ }^{\mathrm{I} 6}$ There is truth in Anderson's observation. The Rwanda tribunal was set up by the Security Council partly to make up for its failure to provide peacekeeping troops with robust powers to prevent the genocide. There is still the reflex of setting up international justice systems in situations where intervention proves impossible or inappropriate. Think of the initiative, to set up an ad hoc tribunal for Syria. More recently, the Netherlands proposed that the Security Council set up an ad hoc Tribunal to prosecute and adjudicate persons (allegedly) responsible for the downing of the Malaysian passenger jet in Ukraine, causing the death of 289 passengers. While there is every reason to identify and punish those who are responsible for gross human rights violations in Syria and those who fired the rocket that hit the Malaysia plane, it is not self-evident that setting up Tribunals is looked at as the appropriate remedy. ICL does not have a strong record in terms of conflict-solving abilities. Against this background, Frederic Mégret's description of ICL as 'palliative to sovereign failure' rings true. ${ }^{\mathrm{I} 7}$

These four factors - (i) ICL's novelty; (ii) its openness, or phrased negatively, 'instability'; (iii) norm entrepreneurialism; and (iv) the ability to push an ideology and political agenda - explain the interest in ICL scholarship. These different agendas,

I4 W.G. Werner, 'Screening International Criminal Justice. A Study of Four Advocacy Documentary Films', p. 3 (on file with author).

I5 Telling is David Crane's opening of the trial of Sessay, Kallon and Gbao: 'Their alleged crimes against humanity cannot justly or practically be ignored, as they were the handmaidens to the beast-the beast of impunity that walked this burnt and pillaged land-its bloody claw marks in evidence on the backs of the hundreds of thousand of victims in this tragic conflict begun on 23 March of I99r'. See www.rscsl.org/Documents/Press/OTP/prosecutor-openingstatemento70504a.pdf. See also D.M. Crane, 'Dancing with the Devil. Prosecuting West Africa's Warlords', (2005) 37 Case Western Reserve Journal of International Law I.

I6 K. Anderson, 'The Rise of International Criminal Law: Intended and Unintended Consequences', (2009) 20 EJIL 33I, at 334.

I7 F. Mégret, 'Justice in Times of Violence', (2003) I4 EJIL 327, at 334. 
however, pull the field of ICL in different directions. Darryl Robinson, in a seminal paper published by LJIL in 2010, referred to this as the 'identity crisis' of ICL. ICL absorbs contradictory narratives; the liberal criminal justice narrative is at one end of the spectrum and human rights activism, endorsing prosecution as the 'fulfilment of the victims' human right to a remedy', at the other end. ICL's popularity comes with great expectations. Inevitably this carries the risk of disappointment in case ICL does not 'deliver'. It is a fact of common knowledge that there is disappointment and even disillusion over the slow pace of justice at the ICC. The non-arrest of high-level defendants such as Al Bashir, the withdrawal of the case against Kenyatta and the recent announcement of South Africa that it is reconsidering its membership of the ICC all feed into a growing feeling of discontentment.

Against this background of heterogeneity, of different agendas and narratives, of growing disillusion with ICL's performance, scholarship has a role to play. ICL scholarship should be more than just dissecting legal provisions and commenting on judgments. ICL needs scholarship that tests assumptions underlying the international criminal justice system, if only to temper expectations. It needs scholarship that engages with those pushing a normative, idealist or political agenda. It needs scholarship that studies the system in its context and uncovers the political and social reality behind the norms.

\section{ORIGINAL SCHOLARSHIP}

In a paper on legal scholarship, Mathias Siems describes how 'academic' legal scholarship differs from research in legal practice. ${ }^{18}$ The message he wants to get across is that good legal scholarship is 'original'. This means that legal research has to go beyond solving a legal problem. ${ }^{\mathrm{I} 9}$ This is what distinguishes legal academics from legal practitioners. Siems' paper provides an interesting framework to reflect on ICL scholarship and its future.

Siems distinguishes between legal scholarship that is 'traditional' and legal scholarship that is 'contextual'. Traditional scholarship - that is scholarship that employs the classic/doctrinal research method ${ }^{20}$ - is mainly interested in a thorough understanding of the law, whereas contextual scholarship studies law in context and is open to interdisciplinary approaches. Siems distinguishes four categories of original research that cover both traditional and contextual scholarship: (i) research that deals with micro-legal questions, i.e., research that analyses a specific legal problem; (ii) research that deals with macro-legal questions, i.e., research that is concerned

I8 M.M. Siems, 'Legal Originality', (2008) 28 Oxford Journal of Legal Studies I47.

I9 Ibid., at I47.

20 The doctrinal research method comes intuitively to lawyers. This makes it difficult for legal scholars to explain to 'outsiders' what they do. Non-legal scholars tend to regard the doctrinal method as insufficiently objective or, worse, unscientific. Hutchinson and Duncan have countered this critique by referring to doctrinal research as a system of discovery: 'It concerns ... rigorous analysis and creative synthesis, the making of connections between seemingly disparate doctrinal strands, and extracting general principles from an inchoate mass of case law'. See T. Hutchinson and N. Duncan, 'Defining and describing what we do: doctrinal legal research', (2012) I7 Deakin Law Review 83; See also, M.A.A. Hoecke (ed.), Methodologies of legal research. Which kind of method for what kind of discipline (2010), I I I-2 I. 
with general concepts, problems and principles of law; (iii) 'scientific legal research', i.e., research that incorporates scientific methodology (qualitative or quantitative research); and (iv) research that deals with non-legal topics, i.e., research that does not take legal questions or problems as a starting-point. Siems does not promote one method of legal research over the other; nor does he discredit one at the expense of the other. Siems admits that for traditional legal scholarship being original is more difficult because the academic does the same - useful but unoriginal - task of a legal practitioner. $^{2 \mathrm{I}}$

In his analysis, Siems mentions a number of ways through which traditional and contextual scholarship can be 'original'. Two of these deserve separate mention since they are relevant for ICL research: theory-building and connecting 'law to life'. Siems' analysis suggests that some form of theory-building is required for traditional scholarship to be 'original'. Providing a new reading of an existing set of rules or principles or the introduction of new ones requires relying on theories/doctrines. ${ }^{22}$

\section{I Theory-building}

ICL is, at its core, criminal law. Criminal law, at least in continental Europe, is one of the last bastions of doctrinal research. Other branches of law, civil law, law and economics, international and European law, have long embraced empirical and interdisciplinary approaches to law. Even to the extent that 'doctrinalists' have felt side-lined. ${ }^{23}$ Criminal law's adherence to doctrinal scholarship can partly be explained by its close link to the legal profession. Criminal law is a discipline that is still predominantly practiced in a courtroom. Its research and teaching is very much centred on how a judge decides a case. Also, the parochial nature of criminal law makes it slow to open up to comparative and interdisciplinary scholarship. Of all branches of law criminal law is most closely associated with sovereignty. It has been referred to as a 'household discipline' reflecting its local background and limited scope of application. ${ }^{24}$ The jus puniendi originally belonged to the pater familias.

This impacts on ICL, which has been influenced heavily by criminal law scholarship. Notable is the influence of German legal scholarship already discussed in the context of norm entrepreneurialism. This scholarship, known for its sophistication in- and outside Germany (Dogmatik), has a very strong theoretical and doctrinal grounding, especially in the area of substantive criminal law. As Markus Dubber puts it, 'the sun never sets on German criminal law'. ${ }^{25}$ It has made Germany one of the major exporters of criminal law and theory. ICL, as a new system of justice, has

2I Siems, supra note i8, at I49.

22 For instance (i) analysis that aims for a deeper understanding of the foundations of legal arguments or the validity of different sources of law; (ii) looking for what could be behind conflicting or converging doctrines; (iii) taking a comparative perspective, by (iv) formulating a normative hypothesis and testing it with available sources. See also Van Gestel, H.-W. Micklitz and M.P. Maduro, Methodoloy in the New Legal World, EUI Working paper 2OI 2/2OI3, at 7 .

23 R. Posner, 'The State of Legal Scholarship Today: A Comment on Schlag', (2009) 97 The Georgetown Law Journal 845. M.R. Scordato, 'Reflections on the Nature of Legal Scholarship in the Post-Realist Era', (2008) 48 Santa Clara Law Review 353, at 380.

24 M.D. Dubber, 'Comparative Criminal Law', in M. Reiman and R. Zimmermann (eds.), Oxford Handbook of Comparative Law (2006), I 288-9.

25 Ibid., at $\mathrm{I} 298$. 
attracted German scholarship where it is regarded as an open invitation to explore how German criminal law doctrines deal with central questions of criminal responsibility (complicity, mens rea, defences). ${ }^{26}$ This type of doctrinal scholarship has its downsides. Sophisticated as it may be, the import of German law into ICL carries the risk of over-theorizing, especially when theories are applied in the abstract. This is exactly what happened in the Katanga and Ngudjolo case at the ICC.

The Pre-Trial Chamber (PTC), in confirming the charges against two Congolese commanders for crimes committed by members of militia under their joint command, relied on the 'control over the crime' theory, modeled on Claus Roxin's theory of Tatherrschaft and Organisationsherrchaft. ${ }^{27}$ The control theory, which was inspired by the Eichmann case, was designed by Roxin to deal with crimes committed by a bureaucracy or any other highly organized entity (army). ${ }^{28}$ Its application, by reading it into the ICC provision on criminal responsibility (Art. 25(3)(a)), had been pushed by a number of scholars, experts in German criminal law. ${ }^{29}$ Applying it to the facts of the Katanga and Ngudjolo case was, however, problematic. Militia, attacking a village in the DRC and committing crimes in the course and the aftermath of the attack, could hardly qualify as a Nazi bureaucracy. The PTC, however, persisted in regarding it as such. The reasoning was that violent and strict training regimes before the attack instilled in the subordinates a propensity to commit crimes. ${ }^{30}$ As if Katanga and Ngudjolo were 'evil watchmakers' who attached a clock to a bomb, wound it up and walked away knowing with reasonable certainty that the device would detonate. ${ }^{3 \mathrm{I}}$ At trial, the control theory did not stand. Ngudjolo was acquitted for lack of evidence and the Trial Chamber eventually convicted Katanga under another mode of liability: contribution to a common criminal purpose (Art. 25(3)(d) ICC Statute).

One cannot escape the impression that scholars pushing for this theory and judges applying it lost sight of the specific African context. The courtroom reality did not connect to the reality of the case; an African militia is not the same as a Nazi bureaucracy. For me, this case goes down in legal history as an example of over-theorizing; of Dogmatik gone wrong. ${ }^{32}$

While I do not want to disqualify doctrinal research in ICL - I am an exponent of that tradition myself - I do see its limits. No other topic has received as much

26 Ibid.

27 Prosecutor v. Katanga and Ngudjolo Chui, Decision on the Conformation of Charges, Case No. ICC-or/o4-o I/o7, P-T. Ch. I, 26 September 2008, paras. 506-8.

28 C. Roxin, Straftaten im Rahmen organisatorischer Machtsapparate', Goltdammer's Archiv für Strafrecht (GA) (I963) translated to English: C. Roxin, 'Crimes as Part of Organized Power Structures', (20II) 9 JICJ I93. See also, C. Roxin, Täterschaft und Tatherrschaft (2006), 242-52, 704-17; C. Roxin, Strafrecht Allgemeiner Teil, Vol. II (2003) 46 et seq.

29 K. Ambos, 'Command responsibility and Organisationsherrschaft: ways of attributing international crimes to the "most responsible", in A. Nollkaemper and H.G. van der Wilt (eds.), System Criminality in International Law (2009), I 27-57; K. Ambos, 'The Fujimori Judgment. A President's Responsibility for Crimes Against Humanity as Indirect Perpetrator by Virtue of an Organized Power Apparatus' (20II) 9 JICJ I37; H. Olasolo, Criminal Responsibility of Senior Political and Military Superiors as Principals to International Crimes (2009); G. Werle and B. Burghardt, 'Indirect Perpetration: A Perfect Fit for International Prosecution of Armchair Killers?' (20I I) 9 JICJ 85 .

$30 \quad$ Katanga and Ngudjolo Confirmation Decision, supra note 27, para. 518.

3I Example derives from M. Osiel, Making Sense of Mass Atrocities (2009) I05.

32 E. van Sliedregt, 'Perpetration and Participation', in C. Stahn (ed.), The Law and Practice of the International Criminal Court (2015) 5 I4. 
doctrinal attention in ICL as criminal responsibility, in particular modes of liability. Having written on the topic myself, I have no problem pointing the finger at myself and concluding that the topic is over-studied. Original traditional scholarship may imply building theories; they should however be good theories, theories that connect the law in the courtroom to the facts on the ground.

\subsection{Connecting law to life}

ICL, in pursuing original scholarship and advancing the field as a whole, can draw on and take inspiration from legal realism. The legal realism movement, by using qualitative and quantitative methods, studies law in action and pays attention to how law is used, gains and changes meaning, in the courtroom and in everyday lives. ${ }^{33}$ The empirical study of law enables exposing the social reality behind the norms. Also, it allows scrutinizing assumptions underlying the international justice system, such as the preventative effect of international trials and the idea that international trials contribute to reconciliation.

ICL has been slow in turning to empirical research. Sarah Nouwen noted in 20I4: '[c]ompared to the massive body of literature on the law applied and made by international criminal tribunals, empirical research on the work of the tribunals is scarce.' 34 This has changed in recent years. In fact, some of the most compelling work in ICL resulted from empirical research. Nancy Combs' empirical evaluation of fact-finding processes at international tribunals was groundbreaking; it cautions against an unconditional belief in witness statements. ${ }^{35}$ Sarah Nouwen's research into the effect and impact of the principle of complementarity in Sudan and Uganda made clear that complementarity will not necessarily have the (anticipated) effect of an increase in domestic proceedings. These are just random examples of a growing body of innovative, empirical scholarship in ICL.

Empirical work is not just about measuring impact and testing assumptions. It can inform us on questions of substantive criminal law. The 'control theory' discussed previously in the context of the Katanga and Ngudjolo case, comes with a controversial 'hierarchical reading' of Article 25 of the ICC Statute. ${ }^{36}$ Those who 'control' others to commit crimes (Art. 25(3)(a)) are more blameworthy than those who are culpable as instigators, aiders and abettors and participants pursuing a common criminal purpose (Art. 25(3)(b-d)). ${ }^{37}$ The text of the provision does not provide for it, however, and those opposing it point out that in ICL in general,

33 G. Shaffer, 'International Legal Theory: International Law and its Methodology: The New Legal Realist Approach to International Law', (20I5) 28 LJIL I 89. Holtermann and Madsen's plead for a European approach to legal realism, distinct from (American) New Legal Pluralism, see Holtermann and Madsen, supra note 8. S.M.H. Nouwen, “'As You Set out for Ithaka”: Practical, Epistemological, Ethical, and Existential Questions about Socio-Legal Empirical Research in Conflict', (20I4) 27 EJIL 227, at 228. International law, where the debate on legal validity is much more central to the discipline than it is in ICL, has always been open to interdisciplinary, and empirical approaches. Holtermann and Madsen, supra note 8, at 2 I I.

35 N.A.Combs, Fact-Finding without Facts. The Uncertain Evidentiary Foundations of International Criminal Convictions (20I3).

36 See for an analysis: J. Ohlin, E. van Sliedregt and T. Weigend, 'Assessing the Control-Theory' (2013) 26 LJIL 725; M. Aksenova, 'The Modes of Liability at the ICC: The Labels that Don't Always Stick', (2015) I 5 International Criminal Law Review 629.

37 Katanga and Ngudjolo Confirmation Decision, supra note 27, paras. 483, 506-8. 
and at the ICC, it is at the sentencing stage that a person's role in the criminal activity is weighed. ${ }^{38}$ Without going into this complex debate, it suffices to point out that the hierarchy thesis, eventually endorsed by the Lubanga Appeals Chamber, ${ }^{39}$ forces ambitious prosecutors to squeeze fact patterns into the control format for no good reason. This is an unwelcome development bearing in mind that 'bad facts make bad law'. Instead of theorizing criminal responsibility in the abstract, we can look at sentencing practices and uncover a pattern that highlights which modes of liability in ICL are regarded as particularly serious. Barbora Hola in her (quantitative) empirical research on sentencing at ad hoc Tribunals shows that there is a direct relationship between modes of liability and sentence severity. ${ }^{40}$ Her research makes clear that (i) aiding and abetting is regarded as a lower form of culpability than ordering or participating in a joint criminal enterprise (JCE); that (ii) at the ICTR, a life sentence is imposed on those who plan or order atrocities to be committed; and (iii) that, at the ICTY, under certain circumstances, a participant in a JCE is regarded as more culpable than a direct/physical perpetrator. ${ }^{4 I}$ According to the hierarchy thesis at the ICC, 'ordering' in Article 25(3)(b) of the Statute implies a lower degree of blameworthiness than perpetration through control (direct or indirect) in Article 25(3)(a) of the Statute. This does not make sense when looking at the law as it is applied in real life.

'Connecting law to life' research does not necessitate the use of empirical research methods. This can be taken from Marjolein Cupido's work on legal casuistry. ${ }^{42} \mathrm{Her}$ analysis of tribunal and ICC judgments shows that legal norms gain their meaning when applied to facts. The concept of crimes against humanity at the ICC is different from that of the ad hoc Tribunals; it adds the requirement that crimes are committed as part of an organizational policy (the 'policy element'). Yet, adopting a casuistic model of analysis and looking at how judges actually decide cases by taking account of the factual consequences of the law makes clear that, when applied to the facts these concepts are very similar. ${ }^{43}$ Cupido's analysis suddenly renders the debate on the 'deviation' of the ICC concept of crimes against humanity from settled Tribunals' jurisprudence rather futile. ${ }^{44}$

38 See Rule I45(I)(c) Rules of Procedure and Evidence of the ICC: 'In addition to the factors mentioned in article 78, paragraph I, give consideration, inter alia, to the extent of the damage caused, in particular the harm caused to the victims and their families, the nature of the unlawful behaviour and the means employed to execute the crime; the degree of participation of the convicted person [italics added, EvS]; the degree of intent; the circumstances of manner, time and location; and the age, education, social and economic condition of the convicted person.'

Prosecutor v. Thomas Lubanga Dyilo, Judgment on the appeal of Mr Thomas Lubanga Dyilo against his conviction, ICC-or/04-0I/06-3I 2 I-Red, A. Ch., I December 20 I4.

40 B. Hola, 'Is ICTY sentencing predictable? An empirical analysis of ICTY Sentencing Practice', (2009) 28 LJIL 79; B. Hola, A. Smeulers and C. Bijleveld, 'International Sentencing Facts and Figures. Sentencing Practice at the ICTY and the ICTR', (20 I I) 9 JICJ 4 I I; B. Hola, C. Bijleveld and A. Smeulers, 'Consistency of international sentencing: ICTY and ICTR case study', (20I2) 9 European Journal of Criminology 539; B. Hola, C. Bijleveld and A. Smeulers, 'Punishment for Genocide - Exploratory Analysis of ICTR Sentencing', (20I I) I I International Criminal Law Review 745.

4I Hola et al., 'International Sentencing Facts and Figures', supra note 40, at 4I 7-I 8.

42 M. Cupido, Facts Matter: A Study into the Casuistry of Substantive International Criminal Law (2015).

43 For an analysis of the debate see M. Cupido, 'The Policy underlying Crimes Against Humanity: Practical Reflections on a Theoretical Debate', (20I I) 22 Criminal Law Forum 275.

Ibid., at $277-82$. 


\subsection{Criminological approaches to ICL}

In 2003, Mark Drumbl advocated for a criminology of international crimes. ${ }^{45}$ In rejecting the domestic analogy thesis where ICL mimics domestic criminal law and its attribution and sentencing theories, he argued in favour of a separate discipline studying international crimes, the situations in which they take place and the interventions that may be taken to prevent such crimes in the future. For a few years there has been a growing interest in criminological research in the area of ICL. We currently witness the emergence of a criminology of international crimes, a 'sister' discipline of ICL. ${ }^{46}$ This new discipline covers a wide range of sub-disciplines and research foci, including victimology, patters of violence, etiology of conflict, and sociological research into group-conduct and collective behavior.

Criminological research in ICL has great explanatory potential. Two examples of recent research are worth mentioning. First of all, criminological research on the nature of international crimes. Rothe and Mullin, who study the phenomenon of mass atrocity by employing mainstream criminology theories on state criminality, published an important study on a typology of international crimes. ${ }^{47}$ Their model provides an integrated theory that can be a frame for systematic analysis and understanding of the etiological factors behind mass atrocities. Another example that illustrates the importance of criminological research is the research by Hola and Van Wijk on post-trial justice; on what happens to persons acquitted, sentenced and convicted by international tribunals. ${ }^{48}$ Empirical analysis shows that international trials have not increased stability and reconciliation in the region of former Yugoslavia. Politically motivated domestic prosecutions extend ethnic hatred while for some former defendants there is no possibility of closure. Van Wijk and Hola's research calls for consideration and interest in post-trial justice. So far, the interest has been limited. The international criminal justice system is mainly interested in prosecuting and trying individuals.

\subsection{Critical approaches to ICL}

In the same way as the New Approaches to International Law (NAIL) movement emerged from dissatisfaction with traditional scholarship in international law, a group of critical scholars emerged in ICL out of frustration over the absence of a meaningful body of critique. Grouped under the label of Critical Approaches to

45 M.A. Drumbl, 'Toward A Criminology of International Crimes' (2003), available via: papers.ssrn.com/ sol3/papers.cfm?abstract_id=4II780.

46 Important publications are, A. Smeulers and R. Haveman, Supranational Criminology: Towards a Criminology of International Crimes (2008); I. Bantekas and E. Mylonaki (eds), Criminological Approaches to International Criminal Law (20I4).

47 D.L. Rothe and C.W. Mullins, 'Toward a Criminology of International Criminal Law: An Integrated Theory of International Criminal Violations', (2009) 33 International Journal of Comparative and Applied Criminal Justice 97.

48 B. Hola and J. van Wijk, 'Life After Conviction; an empirical analysis', (20I4) I2 JICJ rog; B. Hola and J. van Wijk, 'Acquittals in International Criminal justice: Pyrrhic Victories?' (manuscript, on file with author). See on the research project 'When Justice is Done. Life after Conviction': cicj.org/research/ when-justice-is-done-life-after-conviction/. 
International Criminal Law (CAICL), a collaboration started in $20 \mathrm{I} 2$ supporting research in this area. ${ }^{49}$ The work has focused on a number of issues: the politics of international criminal justice,,$^{50}$ Western dominance, $5^{5 \mathrm{I}}$ and the analysis of international criminal justice as donor-driven justice. ${ }^{52}$ This Journal has given a podium to many of these voices.

We owe much to the reflexivity of critical legal scholarship (CLS). While CLS has been accused of reductivism, by regarding law as a mere tool of domination that does not exist independently from politics, it seems to me it enriches ICL scholarship. By adopting the external perspective, by 'looking from the wall',53 ICL scholars and practitioners gain a better understanding of what international criminal justice is about. This is especially relevant since ICL is more than 'just' a criminal justice system. It comes with a context of stakeholders each pushing their own agenda. Critical scholarship engages with the context, with the political agenda behind ICL. CLS offers insights that may impact very concretely on how international trials are run. Marti Koskeniemmi's work on show trials ${ }^{4}$ and recent research by Werner ${ }^{55}$ and Stolk ${ }^{56}$ on the 'story' of ICL, on performativity, may make legal practitioners realize what their role is in creating a certain narrative of international criminal justice. This is relevant in managing expectations and increasing the legitimacy of the system of international criminal justice.

\section{Conclusion}

Currie has a point when he observes that ICL is over-studied. On the topics of modes of liability and substantive ICL, I agree with him. He does, however, ignore recent developments. As Sergey Vasiliev writes in his editorial in the previous issue of this Journal, ICL scholarship is changing direction. ${ }^{57}$ Research is not just about dissecting legal provisions. It is increasingly about studying ICL at the intersection

49 For more information and a bibliography see the CAICL website : www.caicl.net/about-caicl/.

50 F. Mégret, 'The Politics of International Criminal Justice', (2002) I3 EJIL I26I; S. Nouwen and W.G. Werner, 'Doing Justice to the Political: The International Criminal Court in Uganda and Sudan', (20I0) 2I EJIL 94I; S. Nouwen and W.G. Werner 'The Law and Politics of Self-Referrals', in A. Smeulers (ed.), Collective Violence and International Criminal Justice: An Interdisciplinary Approach (2010); T. Skouteris, 'The New Tribunalism: Strategies of (De)Legitimation in the Era of International Adjudication', (2006) I 7 Finnish Yearbook of International Law 307; I. Tallgren, 'We Did It? The Vertigo of Law and Everyday Life at the Diplomatic Conference on the Establishment of an International Criminal Court', (I999) I 2 LJIL 683; I. Tallgren, 'The Sensibility and Sense of International Criminal Law', (2002)I3 EJIL 56r.

5I F. Mégret, "From "Savages" to "Unlawful Combatants": A Postcolonial Look at International Humanitarian Law's "Other”, in A. Orford (ed.), International Law and its Others (2006); 'International Criminal Law: An Ideology Critique' (2013) 26 LJIL 70I.

52 S. Kendall, “Donors” Justice: Recasting International Criminal Accountability', (2OI I) 24 LJIL 585.

53 Dov Jacobs in his LJIL editorial criticizes the claim and the merit of the external perspective of CLS: D. Jacobs, 'Sitting on the Wall, Looking in: Some Reflections on the Critique of International Criminal Law', (20I5) 28 LJIL I.

54 M. Koskeniemmi, 'Between Impunity and Show Trials', (2002) 6 Max Planck Yearbook of United Nations Law I.

55 Supranote I4.

56 Supra note I3.

57 S. Vasiliev, 'On Trajectories and Destinations of International Criminal Law Scholarship', (20 15) 28 LJIL 70 I. 
with other legal disciplines and about opening up to non-doctrinal approaches to ICL. The scholarship discussed in this editorial is illustrative of this trend. Speaking on a personal note, this is a liberating experience. It is important to engage with the social and political realties beyond the legal norms. ICL needs more 'contextual' approaches to legal scholarship. 